\title{
Fecal microbiota transplantation: Literature review
}

\author{
R. Everett Stafford * \\ Houston Methodist Hospital, Houston, United States
}

Received: September 6, 2015

Accepted: February 15, $2016 \quad$ Online Published: March 11, 2016

DOI: $10.5430 /$ jnep.v6n6p79

URL: http://dx.doi.org/10.5430/jnep.v6n6p79

\begin{abstract}
Objective: Despite the advancement of antimicrobial treatments, Clostridium difficile infection (CDI) remains the most common cause of nosocomial infectious diarrhea in adults, and is increasing in frequency and severity in the United States. The reduced efficacy of antimicrobial treatment therapies is a real concern among practitioners and has fuelled the search for alternative treatment options. Fecal Microbiota Transplantation (FMT) has been reported as a safe and effective treatment for CDI for more than 50 year, but has failed to make its way into common practice. The aim is to assess current literature pertaining to the efficacy of FMT as a treatment option for CDI using the Stetler model.

Method: An electronic search using CINHAL Complete, MEDLINE, and Cochrane databases, limited only to articles from academic journals that had full text access and that were published within the last five years. Selection criteria were systematic reviews, and original research studies that used FMT, regardless of delivery modality, for the treatment of recurring and/or refractory CDI (rCDI) and that had laboratory confirmed results and that reported follow-up.

Conclusion: While there is an abundance of literature reporting FMT as a safe and durable practice, most of the published literature consists of case studies and retrospective reviews. The analysis of the selected articles suggests FMT has a substantial effect for the treatment of recurrent CDI. Only three RCTs appear to have been published and majority of the systematic reviews predate the RCTs. More controlled studies with adequate sample sizes are needed before establishing FMT as best practice.
\end{abstract}

Key Words: Fecal microbiota Transplantation, Clostridium difficile infection

\section{INTRODUCTION}

According to the Centers for Disease Control and Prevention (CDC), Clostridium difficile infection (CDI) is associated with about 14,000 deaths annually. ${ }^{[1]}$ Nearly one-third of individuals who have received treatment with metronidazole or vancomycin for a first episode of CDI experience a repeat episode. Rates of recurrence increase to as much as $65 \%$ after the second episode. ${ }^{[2,3]}$ In 2007, a new strain, C. difficile ribotype 027 , emerged and is being implicated for an increase in treatment failures with the conventional antibiotic therapy for CDI. ${ }^{[4]}$ The increasing number of treatment failures, coupled with the high recurrence rates, creates problem of epidemic proportions and a real concern among practitioners.

Fecal Microbiota Transplantation (FMT) is presently an under-researched procedure that shows promise as a viable alternative to the current treatment standards for CDI. FMT is a procedure whereby fecal matter obtained from a healthy donor is administered to an individual suffering from CDI, with an end-goal of correcting the imbalance of gut microbiota. The purpose of this paper is to assess evidence in selected literature pertaining to FMT as a treatment option for CDI, using the Stetler model.

The Stetler model contains five phases. Phase 1 includes

\footnotetext{
* Correspondence: R. Everett Stafford, BS, RN, CCRN; Email: restafford@ houstonmethodist.org; Address: Houston Methodist Hospital, Houston, United States
}

Published by Sciedu Press 
identification of a potential issue or problem, as well as, a meaningful literary search. ${ }^{[5]}$ To facilitate a meaningful literary search regarding best practices pertaining to efficacy of CDI treatment, the following PICO (Population, Intervention, Comparison group, Outcome) question was formulated: In adults with recurrent or refractory Clostridium difficile Infection, what is the effect of Fecal Microbiota Transplantation on the resolution and recurrence of CDI associated diarrhea?

\section{LITERATURE REVIEW}

A Boolean search of CINHAL Complete, MEDLINE, and Cochrane databases was performed using the following terms: "FMT", "Fecal Microbiota Transplant*" and "clostridium difficile". Search criteria were articles published in peer reviewed academic journals between 2011 to July 2015 that focused specifically on the efficacy of Fecal Microbiota Transplantation in the treatment of clostridium difficile in individuals over the age of 18. Articles not in English and articles not related to human subjects were excluded, yielding 89 articles. A title relevancy review resulted in forty-six articles that warranted abstract review and a reference list search. Selection criteria were systematic reviews of research conducted between 2011 - 2015, and original research studies that used FMT, regardless of delivery modality, for the treatment of recurring and/or refractory CDI (rCDI) and that had laboratory confirmed results and that reported follow-up. Studies that included immunocompromised patients or patients with coexisting gastrointestinal issues were excluded along with case studies that didn't provide sample size rationale were excluded in an effort to minimize the selection of articles with inherent biases. In instances where two separate authors reviewed the same cohorts, the most recent one was chosen. Five articles were selected to be critiqued and summarized.

Van Nood et al. ${ }^{[6]}$ conducted an open-label, RCT in the Netherlands to compare the clinical outcome of duodenal infused FMT to two vancomycin control group therapies. The researchers defined primary end point (cure) as CDI symptom resolution without recurrence for 10 weeks posttreatment and the secondary end point as resolution without recurrence for 5 week post-treatment. Randomization software was involved in assigning 43 patients into either the FMT group $(n=16)$ or to one of two control arms; vancomycin-only $(\mathrm{n}=12)$ or vancomycin with bowel lavage $(n=13)$. Baseline demographic and clinical data were described and groups were assessed using the Kruskal-Wallis test, and Fisher's exact or chi-square tests. No statistically significant differences were identified. Clinical resolution was seen in $81 \%$ of the FMT group after the first infusion, compared to $31 \%(p=.008)$ and $23 \%(p=.003)$ in the vancomycin-only and vancomycin with lavage groups respectively. The trial was terminated according to the HaybittlePeto stop rule when the control arm response rates were considerably lower than the $60 \%$ assumed in the calculation of the sample size. Two of the three treatment failures from the FMT group were cured after the second donor stool infusion, resulting in an overall cure rate to $94 \%(p<.001$; 99.9\% CI). Adverse events related to FMT procedure were mild, self-limiting, and resolved within three hours in all cases. Noteworthy, the success of duodenal infused FMT in this study was extended off protocol to 18 patients who had initially failed the antibiotic therapy with 15 (83\%) having clinical resolution. ${ }^{[6]}$

Cammarota et al. ${ }^{[7]}$ conducted an open-label, RCT in the United States to compare the clinical outcome of colonoscopic infused FMT to a vancomycin control group. The primary end point (cure) was defined as CDI symptom resolution without recurrence for 10 weeks post-treatment, and the secondary end point as toxin negative without recurrence for 5 and 10 weeks post-treatment. Block Randomization was used to allocate 39 patients into either the treatment group $($ FMT $n=20)$ or the control arm (vancomycin $n=19)$. Baseline demographic and clinical data were described and the groups were assessed using the Student's $t$-test and Fisher's exact probability test. No statistically significant differences were identified. Clinical resolution was seen in 13 of the $20(65 \%)$ patients in the FMT group after the first infusion, compared to 5 of the 19 (26\%) in the vancomycin group. All first-infusion treatment failures in the FMT group were subsequently diagnosed with pseudomembranous colitis (PMC) and received a series of additional FMT infusions. Five of the 7 were ultimately cured; the remaining 2 died from suspected CDI related complications. The overall cure rate for the FMT arm was $90 \%(p<.001 ; 99.9 \% \mathrm{CI})$. Noteworthy, the 2 FMT treatment failures were the first to receive the FMT treatment and died from suspected CDI related complications. The FMT infusion protocol for PMC was amended as a result. A planned interim analysis, FMT showed a significantly higher efficacy than vancomycin and the trial was terminated according to the Haybittle-Peto stop rule. Adverse events related to the FMT procedure were self-limiting, and resolved within 12 hours. $^{[7]}$

Youngster et $a l .{ }^{[3]}$ conducted an open-label, randomized controlled study at Massachusetts General Hospital to evaluate the efficacy of FMT administered via colonoscopy (cFMT) and FMT administered via nasogastric tube (nFMT) for treatment of rCDI. A total of 20 participants were randomly assigned to a treatment group (10 participants per treatment arm). The researchers assessed the efficacy of the randomization through a comparison of the baseline characteristics 
Table 1. Evidence Summary

\begin{tabular}{|c|c|c|c|c|c|}
\hline Authors & $\begin{array}{l}\text { van Nood E., Vrieze A., } \\
\text { Nieuwdorp M, Fuentes S, } \\
\text { Zoetendal E.G., de Vos } \\
\text { W.M., Visser C.E., Kuijper } \\
\text { E.J., Bartelsman J.F., } \\
\text { Tijssen, J.G., Speelman P., } \\
\text { Dijkgraaf M.G., Keller J.J. }\end{array}$ & $\begin{array}{l}\text { Kassam Z., Lee C.H., } \\
\text { Yuan Y., Hunt R.H. }\end{array}$ & $\begin{array}{l}\text { Satokari R., Mattila E., } \\
\text { Kainulainen V., } \\
\text { Arkkila P. E. T. }\end{array}$ & $\begin{array}{l}\text { Youngster I., Sauk J., Pindar C., } \\
\text { Wilson R.G., Kaplan J.L., Smith } \\
\text { M.B., Alm E.J., Gevers D., Russell } \\
\text { G.H., Hohmann E.L. }\end{array}$ & $\begin{array}{l}\text { Cammarota G., Masucci L., } \\
\text { Ianiro G., Bibbò S., Dinoi G., } \\
\text { Costamagna G., Sanguinetti } \\
\text { M., Gasbarrini A. }\end{array}$ \\
\hline Pub Yr. & 2013 & 2013 & 2014 & 2014 & 2015 \\
\hline Sample & $\begin{array}{l}\text { Adult over the age of } 17 \\
\text { admitted into a non-ICU } \\
\text { hospital setting with a life } \\
\text { expectancy } \geq 3 \text { months, and a } \\
\text { microbiologically confirmed } \\
\text { relapse of C. difficile infection } \\
\text { after at least one course of } \\
\text { adequate antibiotic therapy ( } \geq \\
10 \text { days of vancomycin } \geq 125 \\
\text { mg q.i.d., or } \geq 10 \text { days } \\
\text { metronidazole } 500 \mathrm{mg} \text { t.i.d.) } \\
\text { Exclusion criteria were an } \\
\text { (expected) prolonged } \\
\text { compromised immunity (due } \\
\text { to recent chemotherapy, } \\
\text { Human Immunodeficiency } \\
\text { Virus [HIV] infection with a } \\
\text { CD4 count }<240, \text { or prolonged } \\
\text { use of prednisolone } \geq 60 \mathrm{mg} \\
\text { per day), pregnancy, use of } \\
\text { antibiotics other than for C. } \\
\text { difficile infection at the day of } \\
\text { inclusion, admission to an } \\
\text { Intensive Care Unit or need for } \\
\text { vasopressive medication for } \\
\text { maintenance of normal blood } \\
\text { pressure. }\end{array}$ & $\begin{array}{l}11 \text { studies were chosen. } \\
\text { Abstract dataand studies with a } \\
\text { sample size less than } 10 \text { were } \\
\text { excluded. Only completed } \\
\text { studies that underwent the full, } \\
\text { rigorous peer-review process } \\
\text { were included. Studies that } \\
\text { used FMT via any delivery } \\
\text { modality for laboratory or } \\
\text { endoscopically proven CDI } \\
\text { with clinical resolution as } \\
\text { primary outcome were } \\
\text { included. }\end{array}$ & $\begin{array}{l}\text { All patients treated by } \\
\text { FMT for CDI through } \\
\text { colonoscopy in Helsinki } \\
\text { University Central } \\
\text { Hospital between } \\
\text { December } 2007 \text { through } \\
\text { February } 2014 \text { without } \\
\text { any further inclusion or } \\
\text { exclusion criteria. } \\
\text { The intervention group } \\
\text { inclusion criteria were } \\
\text { confirmed recurrent CDI } \\
\text { despite antimicrobial } \\
\text { treatment; the exclusion } \\
\text { criteria were the } \\
\text { contraindication for } \\
\text { performing clonic lavage } \\
\text { or colonoscopy, and } \\
\text { need for continuous } \\
\text { antibiotic treatment for } \\
\text { other indication than } \\
\text { CDI, and the inability to } \\
\text { understand the treatment } \\
\text { nature (dementia). }\end{array}$ & $\begin{array}{l}\text { Individuals aged } 7-90 \text { with at least } 3 \\
\text { recurrences of CDI or } 2 \text { episodes of CDI } \\
\text { resulting in hospitalization. } \\
\text { Exclusion criteria included presence of } \\
\text { anatomic contraindication to NGT or } \\
\text { colonoscopy, delayed gastric emptying } \\
\text { syndrome, recurrent aspirations, } \\
\text { pregnancy, significantly compromised } \\
\text { immunity (immunosuppressive } \\
\text { medications, recent chemotherapy, } \\
\text { decompensated liver cirrhosis, } \\
\text { advanced human immunodeficiency } \\
\text { virus }[\mathrm{HIV}] / \text { AIDS [CD } 4 \text { count }<250 \\
\text { cells/ } / \mu \mathrm{l}] \text {, neutropenia with absolute } \\
\text { neutrophil count }<1,000 / \mu 1, \text { recent bone } \\
\text { marrow transplant, or other cause of } \\
\text { severe immunodeficiency), and having } \\
\text { a history of significant allergy to foods } \\
\text { not excluded from the donor diet. }\end{array}$ & $\begin{array}{l}\text { Adults over the age of } 17 \text { with a } \\
\text { life expectancy } \geq 3 \text { months, able } \\
\text { to undergo colonoscopy, and a } \\
\text { recurrence of C. difficile } \\
\text { infection after one or more } \\
\text { courses of specific antibiotic } \\
\text { therapy ( } \geq 10 \text { days of } \\
\text { vancomycin } \geq 125 \mathrm{mg} \text { q.i.d., or } \\
\geq 10 \text { days metronidazole } 500 \\
\text { mg t.i.d.) were included. C. } \\
\text { difficile infection was defined } \\
\text { as (i) diarrhea }(\geq 3 \text { loose or } \\
\text { watery stools per day for at least } \\
2 \text { consecutive days, or } \geq 8 \text { loose } \\
\text { stools in } 48 \text { hours) and (ii) a } \\
\text { positive C. difficile toxin stool } \\
\text { test. } \\
\text { Exclusion criteria were } \\
\text { prolonged immunodeficiency } \\
\text { due to recent chemotherapy; } \\
\text { human immunodeficiency virus } \\
\text { (HIV) infection; prolonged use } \\
\text { of steroids; pregnancy; use of } \\
\text { antibiotics other than } \\
\text { metronidazole, vancomycin or } \\
\text { fidaxomicin at baseline; } \\
\text { admission to an intensive care } \\
\text { unit; requirement for vasoactive } \\
\text { drugs; and other infectious } \\
\text { causes of diarrhea. }\end{array}$ \\
\hline Independent V. & $\begin{array}{l}\text { 1. Fresh FMT (duodenal) } \\
\text { preceded by abbreviated } \\
\text { regimen of vancomycin and } \\
\text { bowel lavage. } \\
\text { 2(a). Standard regimen of } \\
\text { vancomycin. } \\
\text { 2(b). Standard regimen of } \\
\text { vancomycin and bowel lavage. }\end{array}$ & & $\begin{array}{l}\text { Frozen FMT via } \\
\text { colonoscopy. }\end{array}$ & $\begin{array}{l}\text { 1. Frozen FMT - Colonic administration } \\
\text { of unrelated frozen stools. } \\
\text { 2. Frozen FMT - Nasogastric } \\
\text { administration of unrelated frozen } \\
\text { stools }\end{array}$ & $\begin{array}{l}\text { 1. FMT via colonoscopy } \\
\text { preceded by bowel cleaning. } \\
2 \text {. Standard regimen of } \\
\text { vancomycin. }\end{array}$ \\
\hline Dependent V. & Incident/occurrence of CDI & & $\begin{array}{l}\text { Incident/occurrence of } \\
\text { CDI }\end{array}$ & Incident/occurrence of CDI & Incident/occurrence of CDI \\
\hline $\begin{array}{l}\text { Research } \\
\text { Design }\end{array}$ & $\begin{array}{l}\text { Open-label, randomized } \\
\text { controlled clinical trial. }\end{array}$ & $\begin{array}{l}\text { Systematic review and } \\
\text { meta-analysis }\end{array}$ & $\begin{array}{l}\text { Observational cohort } \\
\text { Study - retrospective } \\
\text { review }\end{array}$ & $\begin{array}{l}\text { Open-label, randomized controlled pilot } \\
\text { study }\end{array}$ & $\begin{array}{l}\text { Open-label, randomized } \\
\text { controlled clinical trial with a } \\
\text { planned 1-year interim analysis. }\end{array}$ \\
\hline $\begin{array}{l}\text { How data } \\
\text { collected }\end{array}$ & $\begin{array}{l}\text { Data gathered by five of the } \\
\text { researchers; Data were } \\
\text { extracted using computer } \\
\text { software. (Agilent) using } \\
\text { laboratory values, } \\
\text { questionnaires, as well as, } \\
\text { verbal report and stool diary } \\
\text { kept by patient, family, and } \\
\text { medical/nursing staff. }\end{array}$ & $\begin{array}{l}\text { Researchers selected } 11 \\
\text { studies using electronic } \\
\text { database search and compiled } \\
\text { data from each }\end{array}$ & $\begin{array}{l}12 \text { weeks of follow-up } \\
\text { evaluations; laboratory } \\
\text { values }\end{array}$ & $\begin{array}{l}\text { PRIMARY: Laboratory values; donor } \\
\text { screened by American Association of } \\
\text { Blood; follow-up phone calls; } \\
\text { interview; and banks donor } \\
\text { questionnaire. } \\
\text { Patients in both groups were followed } \\
\text { with structured questionnaires } \\
\text { administered on days } 1,2,3,7,14 \text {, and } \\
21 \text {, and at } 2 \text { and } 6 \text { months after the } \\
\text { procedure (primarily by phone). } \\
\text { modification of the Common } \\
\text { Terminology Criteria for Adverse } \\
\text { Events version } 3.0 \text { (approved by the } \\
\text { FDA and IRB. }\end{array}$ & $\begin{array}{l}\text { Lab values; verbal report and } \\
\text { stool diary kept by patient, } \\
\text { family, and medical/nursing } \\
\text { staff. }\end{array}$ \\
\hline $\begin{array}{l}\text { Summary of } \\
\text { findings }\end{array}$ & $\begin{array}{l}\text { FMT therapy resulted in better } \\
\text { treatment outcomes compared } \\
\text { to both vancomycin-only and } \\
\text { vancomycin with lavage in } \\
\text { patients with recurrent C. } \\
\text { difficile infection. } \\
\text { 1. FMT cured } 15 \text { of the } 19 \\
\text { patients }(94 \%) ; \\
2 . \text { Vancomycin-only therapy } \\
\text { cured four of the } 13 \text { patients } \\
(31 \%) ; \\
3 . \text { Vancomycin + lavage cured } \\
\text { three of the } 13 \text { patients }(23 \%) \text {. }\end{array}$ & $\begin{array}{l}\text { The } 11 \text { studies yielded } 273 \\
\text { patients, of which } 245 \\
\text { experiences clinical resolution. }\end{array}$ & $\begin{array}{l}\text { The comparison between } \\
\text { FMT (frozen) to the } \\
\text { retrospective review of } \\
\text { the FMT (fresh) shows } \\
\text { no difference in efficacy } \\
\text { between the groups } \\
(96 \%) \text {, and the } 1 \text {-year } \\
\text { follow-up }(88 \%) \text {. }\end{array}$ & $\begin{array}{l}\text { FMT using a frozen inoculum from } \\
\text { unrelated donors was effective in } \\
\text { treating relapsing CDI, even in patients } \\
\text { with multiple recurrences. } \\
\text { Overall cure rate of } 90 \% \text { at } 8 \text { weeks } \\
\text { between the Colonic group }(100 \%) \text { and } \\
\text { NGT group }(80 \%) \text {. } \\
\text { Of } 20 \text { patients in both study arms, } 14 \\
\text { were cured after the first FMT }(70 \%): 8 \\
\text { in the colonoscopy group }(80 \%) \text { and } 6 \\
\text { in the NGT group ( } 60 \% ; p=.628) \text {. } \\
\text { Four of the } 5(80 \%) \text { that elected to have } \\
\text { a second FMT were cured. }\end{array}$ & $\begin{array}{l}\text { FMT therapy resulted in better } \\
\text { treatment outcomes compared } \\
\text { to vancomycin therapy in } \\
\text { patients with recurrent C. } \\
\text { difficile infection. } \\
\text { 1. FMT cured } 18 \text { of the } 20 \\
\text { patients }(90 \%) \text {; } \\
\text { 2. Vancomycin therapy cured } \\
\text { five of the } 19 \text { patients }(26 \%) \text {. }\end{array}$ \\
\hline $\begin{array}{l}\text { Identified } \\
\text { strengths }\end{array}$ & $\begin{array}{l}\text { Randomizing into groups, } \\
\text { appropriate statistical analysis. }\end{array}$ & $\begin{array}{l}\text { Selection criteria were } \\
\text { stringent. Eligibility } \\
\text { assessment and data extraction } \\
\text { were performed by two } \\
\text { independent researchers. } \\
\text { Elements of the Centre for } \\
\text { Reviews and Dissemination } \\
\text { checklist and the National } \\
\text { Institute of Clinical Excellence } \\
\text { quality assessment for case } \\
\text { series checklist were employed } \\
\text { to determine study quality. }\end{array}$ & $\begin{array}{l}\text { Performed in the same } \\
\text { clinical setting, using the } \\
\text { same protocols. }\end{array}$ & $\begin{array}{l}\text { Randomizing into groups, appropriate } \\
\text { statistical analysis. }\end{array}$ & $\begin{array}{l}\text { Randomizing into groups, } \\
\text { appropriate statistical analysis. }\end{array}$ \\
\hline $\begin{array}{l}\text { Identified } \\
\text { weaknesses }\end{array}$ & $\begin{array}{l}\text { Lack of blinding; exclusion of } \\
\text { ICU admissions; possible bias } \\
\text { in selection process. }\end{array}$ & $\begin{array}{l}\text { Literature reviewed composed } \\
\text { largely of non-controlled } \\
\text { observational studies. }\end{array}$ & $\begin{array}{l}\text { Retrospective review - } \\
\text { Hospital protocols were } \\
\text { in place, but the } \\
\text { retrospective approach } \\
\text { assumes compliance. }\end{array}$ & $\begin{array}{l}\text { Lack of blinding; exclusion of ICU } \\
\text { admissions; possible bias in selection } \\
\text { process. }\end{array}$ & $\begin{array}{l}\text { Lack of blinding; same donor } \\
\text { used; exclusion of ICU } \\
\text { admissions; possible bias in } \\
\text { selection process. }\end{array}$ \\
\hline Level of study & Level II & Level III & Level IV & Level II & Level II \\
\hline
\end{tabular}


using the Mann-Whiney test and Fisher's exact test. Data were collected through laboratory values and follow-up structured questionnaires administered primarily by phone. Outcome data were assessed using a mixed-model analysis of variance, according to the intention to treat principle. All statistical tests were 2 -sided and a $p$-value $<.05$ was considered statistically significant and analyzed using SPSS statistical software. Fourteen of 20 participants $(70 \%)$ had clinical resolution after the first FMT infusion $(p=.628)$. Of the 6 remaining, one refused a second treatment, 5 received a second infusion, of which 4 had clinical resolution. Overall cure rate of $90 \%$ (80\% of nFMT and $100 \%$ of the cFMT; $p$ $=.63$ ). At the pre-determined 8-week follow-up, no patient had recurrence of CDI symptoms. The study compared two routes of FMT administration without a non-FMT control group and was not adequately powered to determine the clinical significance of the outcome. Despite these limitations, the overall cure rate still suggests that FMT is effective for treating CDI. ${ }^{[3]}$

Staokari et al. ${ }^{[8]}$ conducted an observational cohort study to compare clinical outcomes of patients who received FMT infusion of fresh stool to an infusion of frozen stool. The medical records of all patients that received FMT via colonoscopy between December 2009 and February 2014 at Helenski University Central Hospital were reviewed retrospectively. Patient follow-up occurred at 12 weeks and one-year post-FMT to collect recurrence data. FMT patients who were receiving antibiotics for any indication other than CDI were excluded. Of the 49 cases reviewed, 26 received fresh stool (fresh FMT) and 23 received stool previously frozen (frozen FMT). Baseline patient characteristics were assessed using the Student's $t$-test, Mann-Whitney U-test, and Fisher's exact test, which determined group differences to be non-significant. The Fisher's exact test was used to assess the treatment outcomes and a $p<.05$ was determined to statistically significant. Clinical resolution at twelve weeks occurred in $96 \%$ in both the fresh FMT ( 25 of 26 cases) and frozen FMT ( 22 of 23 cases) groups. At one year, 25 of the 26 patients in the fresh FMT group and 17 of the 23 in the frozen FMT group were available for follow-up, of which $88 \%$ of both groups reported clinical resolution. No specific $p$-values were provided in the text or supplemental tables. Staokari et al. addressed the absence of statistical differences narratively in the text of the report. ${ }^{[8]}$

Kassam et al. ${ }^{[9]}$ performed a systematic review and metaanalysis to examine the efficacy and safety of FMT as treatment for CDI. The researches performed a literary search with stringent eligibility criteria that resulted in the inclusion of 11 studies in their review, which was composed largely of non-controlled observational studies. Validated tools were used to assess the quality of each article. Weighted (WPR) and un-weighted pooled resolution rates (UPR) were calculated with a 95\% CI. WPR were analyzed using the DerSimonian-Laird method, and the heterogeneity between studies was assessed using the $\mathrm{I} 2$ statistic and the Cocran Q test. The 11 studies yielded 273 patients, of which 245 experiences clinical resolution (UPR 89.7\%; WPR 89.1\%; $95 \%$ CI 84\%-93.3\%). No statistically significant difference in heterogeneity (Cochran $\mathrm{Q}$ test $p=.23$; I2 = 33.7) was found. ${ }^{[9]}$

\section{SUMMARY}

Phase III of the Stetler model is a comparative evaluation of the five selected articles in terms of substantiating evidence, fit of setting, feasibility, and current practice. ${ }^{[5]}$ The articles include are 3 RCTs (Level II), an observational cohort study (Level IV), and a systematic review and meta-analysis (Level III), all of which suggest FMT is an effective treatment for CDI (see Table 1). Only two of the five studies compared the efficacy of FMT to a non-FMT control. The other three compared efficacy between two FMT groups. Adverse events related to FMT infusion seem to be self-limiting and short-lived, however, Cammarota et al. ${ }^{[7]}$ reported making a protocol amendment after two patients from the FMT group died from apparent CDI complications. There were a number of themes that appeared frequently in the studies, such as, the abbreviated vancomycin dose and bowel lavage that preceded FMT and the additional donor stool infusions for initial treatment failures. More noticeable, however, were the variations in processes between the studies. Many of the commonalities between studies varied in the details, such as, participant screening and follow-up times, donor screening and donor stool preparation, methods of infusion (nasogastric tube or colonoscopic), and points of infusion (distal or proximal colon or stomach). While there is an abundance of literature reporting FMT as a safe and durable practice, there is a paucity of high-quality studies (Level I or II), which makes its acceptance as best practice challenging.

Table 2. Success Rates of FMT Treatment

\begin{tabular}{lll}
\hline Article & Pub Yr. & Clinical Resolution/Participants (\%) \\
\hline Van Nood et al. & 2013 & $15 / 16(94)$ \\
Cammarota et al. & 2015 & $18 / 20(90)$ \\
Staokari et al. & 2014 & $47 / 49(96)$ \\
Kassam et al. & 2013 & $245 / 273(90)$ \\
Youngster et al. & 2014 & $18 / 20(90)$ \\
\hline Total & & $\mathbf{3 4 3 / 3 7 8 ~ ( 9 1 )}$ \\
\hline
\end{tabular}

\section{Conclusion}

Phases IV and V of the Stetler model involve planning the implementation of the evidence into practice. ${ }^{[5]}$ From the 
analysis of the selected articles, there is sufficient evidence to suggest FMT has a substantial effect for the treatment of recurrent CDI. Clinical resolution was reported in $91 \%$ (343/378) of the participants that received FMT (see Table 2). However, most of the literature consists of case studies and retrospective reviews. Only three RCTs appear to have been published and majority of the systematic reviews predate the RCTs. More controlled studies with adequate sample sizes are needed to explore the safety aspects of FMT before establishing FMT as best practice. Another focus on future research might be to better understand, identify and isolate the specific component(s) of the stool responsible for positive outcomes.

\section{REFERENCES}

[1] Centers for Disease Control and Prevention. CDC-Clostridium difficile Infection - HAI 2015. Available from: http://www.cdc.gov/ HAI/organisms/cdiff/Cdiff_infect.html

[2] Drekonja D, Reich J, Gezahegn S, et al. Fecal Microbiota Transplantation for Clostridium difficile Infection: A Systematic Review. Ann Intern Med. 2015; 162(9): 630-8. PMid:25938992 http: //dx.doi.org/10.7326/M14-2693

[3] Youngster I, Sauk J, Pindar C, et al. Fecal microbiota transplant for relapsing Clostridium difficile infection using a frozen inoculum from unrelated donors: a randomized, open-label, controlled pilot study. Clin Infect Dis. 2014; 58(11): 1515-22. PMid:24762631 http://dx.doi.org/10.1093/cid/ciu135

[4] Mattila E, Uusitalo-Seppälä R, Wuorela M, et al. Fecal transplantation, through colonoscopy, is effective therapy for recurrent Clostridium difficile infection. Gastroenterology. 2012; 142(3): 490-6. PMid:22155369 http://dx.doi.org/10.1053/j.gastr 0.2011 .11 .037

[5] Stetler CB. Updating the Stetler Model of research utilization to facilitate evidence-based practice. Nurs Outlook. 2001; 49(6):
272-9. PMid:11753294 http://dx.doi.org/10.1067/mno. 200 1.120517

[6] van Nood E, Vrieze A, Nieuwdorp M, et al. Duodenal infusion of donor feces for recurrent Clostridium difficile. N Engl J Med. 2013; 368(5): 407-15. PMid:23323867 http://dx.doi.org/10.1056 /NEJMoa1205037

[7] Cammarota G, Masucci L, Ianiro G, et al. Randomised clinical trial: faecal microbiota transplantation by colonoscopy vs. vancomycin for the treatment of recurrent Clostridium difficile infection. Aliment Pharmacol Ther. 2015; 41(9): 835-43. PMid:25728808 http://dx.doi.org/10.1111/apt.13144

[8] Satokari R, Mattila E, Kainulainen V, et al. Simple faecal preparation and efficacy of frozen inoculum in faecal microbiota transplantation for recurrent Clostridium difficile infection-an observational cohort study. Aliment Pharmacol Ther. 2015; 41(1): 46-53. PMid:25355279 http://dx.doi.org/10.1111/apt.13009

[9] Kassam Z, Lee CH, Yuan Y, et al. Fecal microbiota transplantation for Clostridium difficile infection: systematic review and meta-analysis. The American Journal of Gastroenterology. 2013; 108(4): 500-8. PMid:23511459 http://dx.doi.org/10.1038/ajg. 2013.59 